\title{
An Environmental Problem Hidden in Plain Sight? Small Human-made Ponds, Emergent Insects, and Mercury Contamination of Biota in the Great Plains
}

\author{
Matthew M. Chumchal* and Ray W. Drenner \\ Biology Department, Texas Christian University, Fort Worth, Texas, USA
}

\begin{abstract}
Mercury ( $\mathrm{Hg})$ contamination of small human-made ponds and surrounding terrestrial communities may be 1 of the largest unstudied Hg-pollution problems in the United States. Humans have built millions of small ponds in the Great Plains of the United States, and these ponds have become contaminated with atmospherically deposited mercury. In aquatic ecosystems, less toxic forms of $\mathrm{Hg}$ deposited from the atmosphere are converted to highly toxic methylmercury $(\mathrm{MeHg})$. Methylmercury is incorporated into the aquatic food web and then can be transferred to terrestrial food webs via emergent aquatic insects. The authors present a conceptual model that describes the movement of $\mathrm{MeHg}$ produced in aquatic ecosystems to terrestrial consumers via insects emerging from small human-made ponds. The authors hypothesize that pond permanence and the level of $\mathrm{Hg}$ contamination of the food web control this emergent insect-mediated flux of MeHg. The highest insect-mediated flux of $\mathrm{MeHg}$ is predicted to be from fishless semipermanent ponds with food webs that are highly contaminated with MeHg. Further development and testing of the conceptual model presented in the present column, particularly in the context of a changing climate, will require research at the regional, watershed, and pond scales. Environ Toxicol Chem 2015;34:1197-1205. (C) 2015 SETAC
\end{abstract}

Keywords-Mercury; Aquatic insect; Bioaccumulation; Environmental transport; Trophic transfer

\section{Introduction}

Humans have built millions of small ponds in the Great Plains of the United States over the last $100 \mathrm{yr}$ [1], and all of these ponds receive mercury $(\mathrm{Hg})$ deposited from the

\section{Address correspondence to m.m.chumchal@tcu.edu}

Published online in Wiley Online Library

(wileyonlinelibrary.com). DOI: 10.1002/etc.2954

2015 SETAC atmosphere [2,3]). In aquatic ecosystems, less toxic forms of $\mathrm{Hg}$ deposited from the atmosphere are converted to highly toxic methylmercury (MeHg) [3-5]. Therefore, the construction of ponds has unintentionally created millions of $\mathrm{MeHg}-$ producing aquatic ecosystems that contaminate not only aquatic consumers but also emergent aquatic insects and the terrestrial consumers that feed on them, including spiders and birds [6-10]. In the present column we present a conceptual model that describes the movement of $\mathrm{MeHg}$ produced in aquatic ecosystems to terrestrial consumers via insects emerging from small human-made ponds in the Great Plains. We hypothesize that pond permanence and the level of $\mathrm{Hg}$ contamination of the food web control this emergent insectmediated flux of $\mathrm{MeHg}$. Mercury contamination of small human-made ponds and surrounding terrestrial communities may be 1 of the largest unstudied $\mathrm{Hg}$-pollution problems in the United States. Our goal is to draw attention to this potentially important but unrecognized environmental issue that may affect the health of wildlife across the Great Plains and other agricultural areas of the United States where small humanmade ponds are common.

\section{Small Human-made Ponds in the Great Plains of the United States}

Until recently, small ponds have been largely ignored by ecologists, and the study of small lentic systems has lagged behind larger-lake limnology over much of the past century [11] (but see Wilbur [12], Swingle [13], and Dendy [14]). Ponds are frequently omitted from descriptions of global cycles and processes, including carbon, energy and radiation, greenhouse gasses, nitrogen, oxygen, phosphorus, 
silicon, sulfur, and water [11]; and we here add $\mathrm{Hg}$ to this list. This oversight has likely resulted from a historical bias within the field of ecology to focus on "natural" over "human-made" ecosystems [15] and from an assumption that small ponds cover an insignificant surface area of the earth and are therefore unimportant in global processes [11]. However, recent inventories suggest that small ponds are more numerous than large lakes and that the spatial extent and surface area occupied by small ponds have been underestimated [11], leading some authors to argue that the importance of small ponds in global processes has not been appreciated $[11,16]$.

The present column focuses on small human-made ponds (defined here to have surface areas smaller than $\sim 1$ ha [17]) in the Great Plains of the United States. Widespread pond construction in agricultural areas of the United States, like the Great Plains, is thought to have begun in the early twentieth century [1]. Small human-made ponds were constructed for a variety of purposes, including water supply for livestock, irrigation, sediment trapping and erosion control, and recreation [14,18]. Beginning in the 1940s and accelerating in the 1950s, large numbers of ponds were built with assistance from the Soil Conservation Service [1]. Swingle [13] estimated that the number of ponds in the United States increased from 20000 in the 1930s to over 2 million by 1965 . The total number of small human-made ponds is now estimated to be as high as 8 million to 9 million, making them the numerically dominant lentic water body type across the conterminous United States [1]. Eighty-five percent of the small ponds in the United States are less than 0.5 ha [18]. The eastern Great Plains has some of the highest densities of small ponds, with $>3$ ponds $/ \mathrm{km}^{2}$ (Figure 1); and the number of small ponds continues to increase at a rate of $1 \%$ to $2 \%$ per year in agricultural areas of the United States [16].

Human-made ponds are transient features of the landscape with average life spans in the Great Plains of less than 50 yr [1]. Most ponds are initially constructed so that they are deep enough to hold water throughout the year, even during periods of low rainfall. Once filled with water, new ponds are rapidly colonized by plants and animals and stocked with fish by humans. Throughout their existence, these small impoundments act as major sediment and carbon sinks because they trap inorganic and organic particles eroded from upstream terrestrial landscapes $[1,18]$. As these ponds age, sediment infilling slowly reduces the depth and volume of the basin, making these ponds more prone to drying and winter kill of fish. Eventually they begin to dry periodically during years with low rainfall but still contain water for long periods of time (months to years). Finally, late in the life of these ponds, sediment infilling reduces the water depth and basin volume to the point that these ponds contain water for only short intervals of time (weeks or months) during the year. Infilling with sediment is the dominant cause of pond disappearance in agricultural areas [1]. Humans can intervene in the ontogeny of ponds by removing sediment from older ponds, restoring

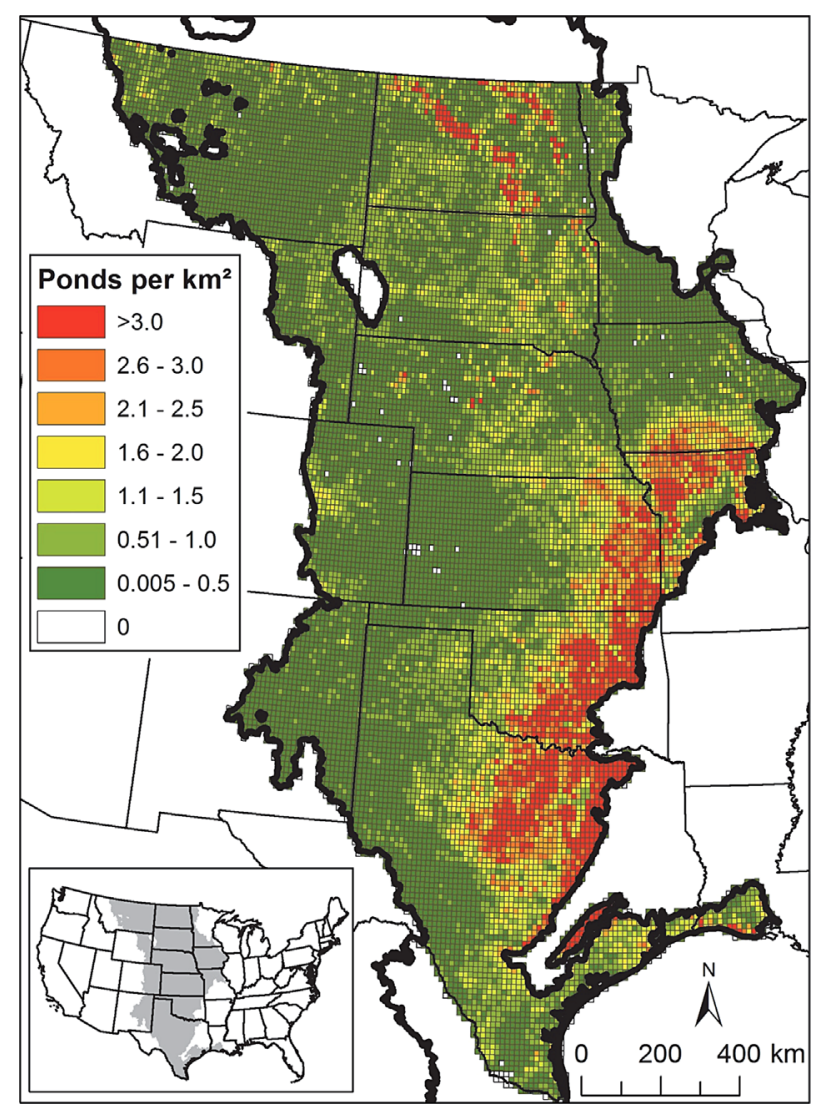

FIGURE 1: Density of small ponds (water bodies $\leq 1 \mathrm{ha}$ ) in 1:24-k quadrangles in the Great Plains ecoregion of the United States (hydrology data from the National Hydrology data set [64], ecoregion data from the US Environmental Protection Agency [65]. In the National Hydrology data set there are approximately 2 million small ponds in the Great Plains, with the highest densities of ponds in the east. In the eastern Great Plains ponds are found at densities of $>3$ ponds $/ \mathrm{km}^{2}$.

them to a permanent state in which they retain water throughout the year.

The ontogeny of ponds and associated change in pond permanence has significant implications for the biotic community structure within ponds. A number of ecologists have contributed to the development of a theoretical framework for understanding how communities in small aquatic ecosystems are shaped by permanence and predators [19-22]. In agreement with this theoretical framework, we have observed 3 general classes of human-made ponds in the Great Plains: 1) permanent fish ponds, 2) semipermanent fishless ponds, and 3) temporary fishless ponds (Figure 2). We define permanent fish ponds as those ponds that hold water over long periods of time (years). Permanent ponds do not dry and do not experience winter kill, allowing them to sustain fish populations $[19,20]$. Fish may be intentionally stocked for recreational purposes, or they may colonize ponds by migrating from upstream or downstream sources. Compared with fishless ponds, ponds with fish have insect communities that are less diverse and have lower biomass and smaller, less active taxa $[19,20]$. We define semipermanent fishless ponds as ponds that contain water over long periods (months to years) but do not contain fish because of periodic drying or 


\section{Animals Commonly Associated With Aquatic Food Webs in the Great Plains}

The construction of small ponds by humans has increased biodiversity in the Great Plains by introducing aquatic food webs in upland areas where streams and natural lakes were not present. Animals commonly associated with aquatic food webs in the Great Plains include spiders (A, long-jawed orb weaver [Tetragnatha sp.]) crustaceans (B, water flea [Daphnia sp.]) insects (C, widow skimmer [Libellula luctuosa]; D, giant water bug [Belostoma flumineum]; E, black and yellow mud dauber [Sceliphron caementarium]; F, mosquito [Aedes vexans]), fish (G, bluegill [Lepomis macrochirus]), frogs $(\mathbf{H}$, northern leopard frog [Rana pipiens]), turtles (I, red-eared slider [Trachemys scripta]), snakes (J, northern water snake [Nerodia sipedon]), birds (K, mallard [Anas platyrhynchos]; L, eastern phoebe [Sayornis phoebe]; M, great blue heron [Ardea herodias]; N, belted kingfisher [Megaceryle alcyon]; O, red-winged black bird [Agelaius phoeniceus]), and mammals ( $\mathbf{P}$, raccoon [Procyon lotor]). Because of their association with aquatic food webs, all of these animals could be contaminated with methylmercury.
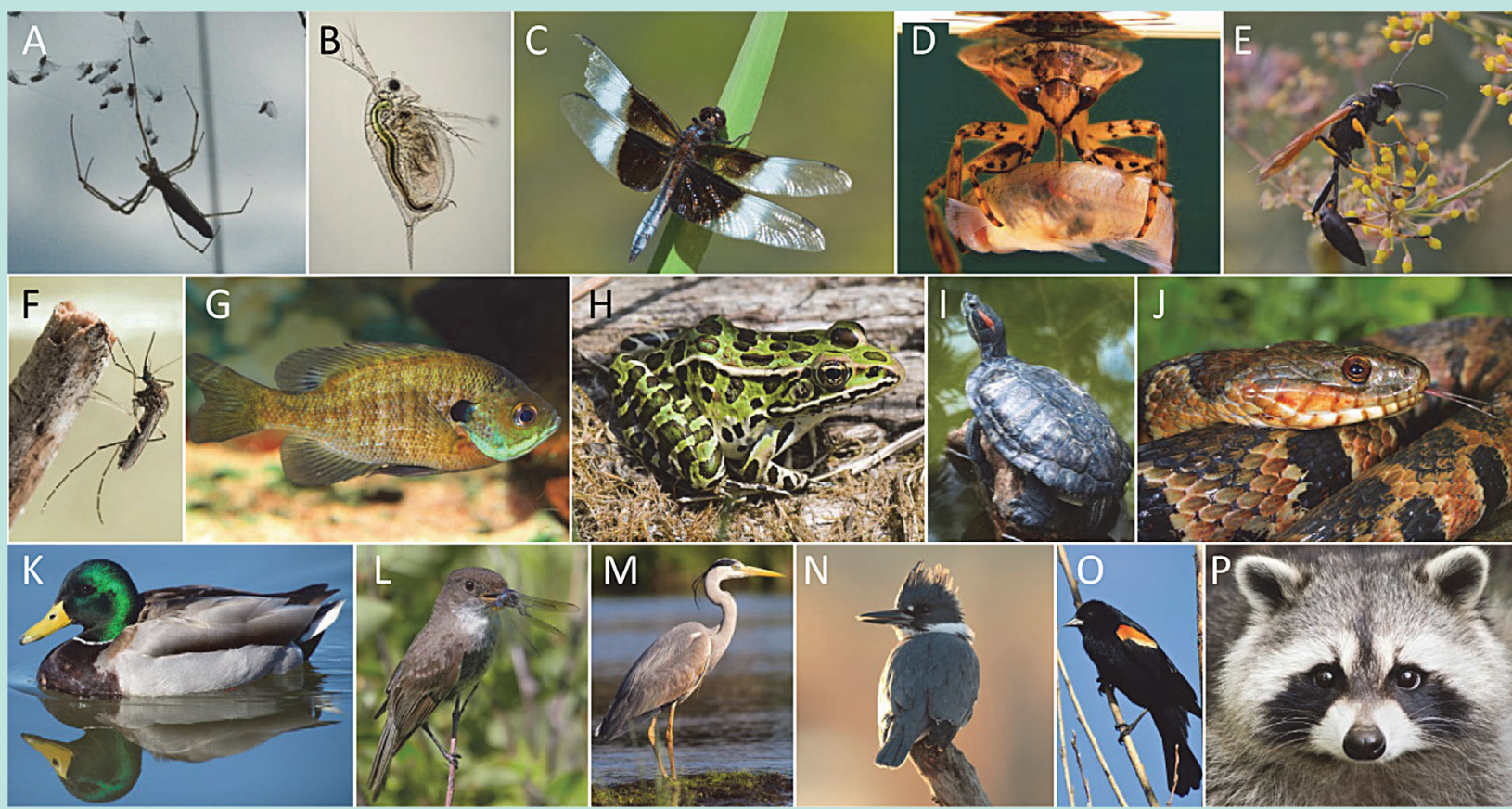

Photo credits: A. Matthew Chumchal; B. Nancy Nehring, iStock; C. PaulReevesPhotography, iStock; D. Andrew Skolnick, Shutterstock; E. Elliotte Rusty Harold, Shutterstock; F. doug4537, iStock; G. Feathercollector, Shutterstock; H. Roger de Montfort, Shutterstock; I. Mojkan, iStock; J. Ivkuzmin, iStock; K. Tom Middleton, Shutterstock; L. Steve Byland,

Shutterstock; M. PhotoL, iStock; N. Megasquib, iStock; O. RCKeller, iStock; P. Toos, iStock.

winter kill. In semipermanent ponds without fish, largebodied, active invertebrate predators like dragonflies replace fish as the top consumers in the food chain [19,20]. Semipermanent fishless habitats that perennially contain water tend to support the highest diversity and overall abundance of large predatory insects [19]. We define temporary fishless ponds as ponds that hold water for only weeks at a time. Temporary ponds contain active, rapidly

Permanent with fish

Semi-permanent fishless

Temporary fishless
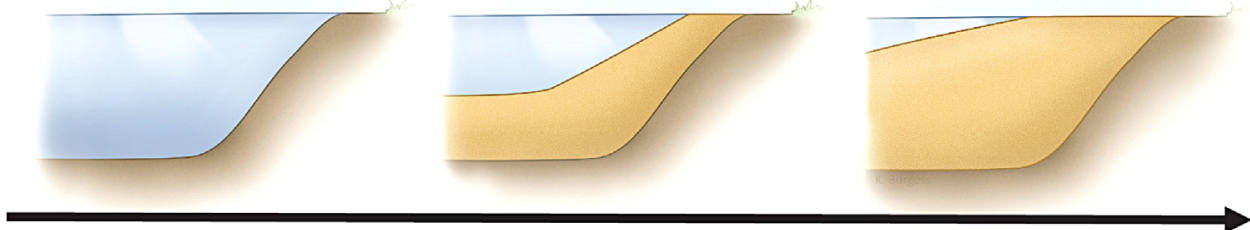

\section{Permanence gradient resulting from sediment infilling}

FIGURE 2: Permanence gradient resulting from sediment infilling. Most small human-made ponds are initially constructed to hold water for long periods of time (years). As ponds age, sediment infilling causes them to become more shallow, and through time they change from permanent with fish to semipermanent without fish and eventually to temporary without fish. 
developing taxa and fewer predators than do semipermanent fishless ponds that hold water over longer periods (months to years) [20]. Temporary fishless ponds have especially diverse beetle and midge communities [19]. Because fish and invertebrate predators are excluded, temporary ponds are unique in that mosquito larvae can be the numerically dominant residents [19]. This view of the relationship between insect communities, pond permanence, and predators is idealized and simplified [20]; but it captures the essential features of the biotic communities that inhabit ponds during their ontogeny. It should be noted that these categories represent points along a dynamic continuum rather than fixed states. Not only does sediment infilling affect permanence over decades but unusually wet or dry years can cause ponds to shift from 1 class to another.

Because pond permanence influences aquatic community structure, permanence also influences insect emergence $[9,10]$ and the potential effects of emergent insects on the surrounding terrestrial environment [23-25]. Insect emergence differs with the class of pond $[9,10]$. For example, in permanent fish ponds with centrachids that feed selectively on large invertebrate prey [26], the biomass of emerging dragonflies can be suppressed to the point that it is relatively similar to the biomass of emerging small-bodied insects, like chironomids and mosquitoes [9]. In semipermanent ponds without fish, the biomass of emerging dragonflies can be much greater than that of small-bodied chironomids and mosquitoes [9]. In temporary ponds without fish, only chironomids and mosquitoes emerge if water retention time is too short for dragonfly life cycles [19,27]. Because the insect taxa that emerge from ponds vary by class of pond, the species of terrestrial consumers that are recipients of organic carbon contained in the tissues of emergent insects will also vary with class of pond. For example, higher densities of insectivorous birds are found around fishless ponds with high mayfly emergence than around fish ponds with low mayfly emergence [25]. The class of pond may also indirectly affect terrestrial community structure. Knight et al. [23] found that plants near ponds that contain fish receive more pollinator visits and are less pollen-limited than plants near fish-free ponds because dragonflies that emerge from fish-free ponds consume insect pollinators and alter pollinator foraging behavior.

\section{Mercury Contamination of the Great Plains}

\section{Mercury cycle}

Mercury contamination of the environment is hazardous to wildlife health $[3,28,29]$. Wildlife are primarily exposed to $\mathrm{MeHg}$ through the consumption of $\mathrm{Hg}$-contaminated prey [29], and relatively low doses can have adverse effects on wildlife health and reproduction $[3,28,29]$. Recent findings indicate that the scope and severity of the $\mathrm{Hg}$ problem for wildlife have been substantially underestimated, and the ecotoxicology of $\mathrm{Hg}$ is an area of active research [28]. For example, terrestrial songbirds have been found to consume MeHg-contaminated prey [30], and songbirds exposed to $\mathrm{MeHg}$ may suffer reduced reproductive success [31].

All areas of the earth have elevated levels of $\mathrm{Hg}$ as a result of widespread atmospheric deposition from anthropogenic sources [3,4]. Mercury deposition rates are estimated to have increased by a factor of 3 to 5 since the industrial revolution [4] and by a factor of 7 to 10 since antiquity [32]. Today the largest anthropogenic sources of environmental $\mathrm{Hg}$ are atmospheric emissions from fossil fuel combustion and small-scale gold mining in developing countries [32]. Mercury is released into the atmosphere, where it can reside for up to $1 \mathrm{yr}$ until being deposited onto the earth's surface, often far from the source $[3,4]$. In general, $\mathrm{Hg}$ deposited on terrestrial surfaces exists in a nonbioaccumulative and relatively nontoxic inorganic form [3-5]. Once deposited on the terrestrial landscape, $\mathrm{Hg}$ can bind strongly to organic matter; and $\mathrm{Hg}$ in soil represents the largest pool of $\mathrm{Hg}$ in the terrestrial environment $[3,4]$. Soil-bound $\mathrm{Hg}$ can be transported to ponds in runoff, where microbes can convert it to the highly toxic and bioaccumulative form $\mathrm{MeHg}$ [3-5]. Organisms at the base of the food web, such as phytoplankton and periphyton, concentrate $\mathrm{MeHg}$ directly from the water [33,34], whereas consumers are exposed to $\mathrm{MeHg}$ primarily through their diets [35-37].

Contaminants, like $\mathrm{MeHg}$, that enter aquatic food webs have the potential to be transferred to terrestrial food webs when aquatic insects that spend part of their life cycle in aquatic ecosystems emerge as adults [6,9,38-42]. For each taxon of emergent insect within a water body, the flux of $\mathrm{MeHg}$ moving from aquatic to terrestrial ecosystems is a product of the taxon's $\mathrm{MeHg}$ concentration and emergent biomass $[9,10]$. In general, the $\mathrm{MeHg}$ concentration of a given taxon is determined by the taxon's position in the food web. Insect taxa with low trophic positions, such as periphyton-grazing caddis flies and chironomids, have relatively low $\mathrm{MeHg}$ concentrations, whereas carnivorous damselflies and dragonflies have relatively high $\mathrm{MeHg}$ concentrations $[6,9,10]$.

\section{Conceptual Model of Insect- mediated Flux of Mehg From Small Human-made Ponds in the Great Plains}

We hypothesize that $\mathrm{MeHg}$ flux of emergent insects from small human-made ponds is controlled by the interaction of 2 major factors: pond permanence and the level of $\mathrm{Hg}$ contamination of the food web (Figure 3). As ponds age, sediment infilling causes them to become more shallow, and through time they change from permanent with fish to semipermanent without fish and eventually to temporary without fish. Our research has shown that the presence or absence of fish regulates insect emergence and the associated 


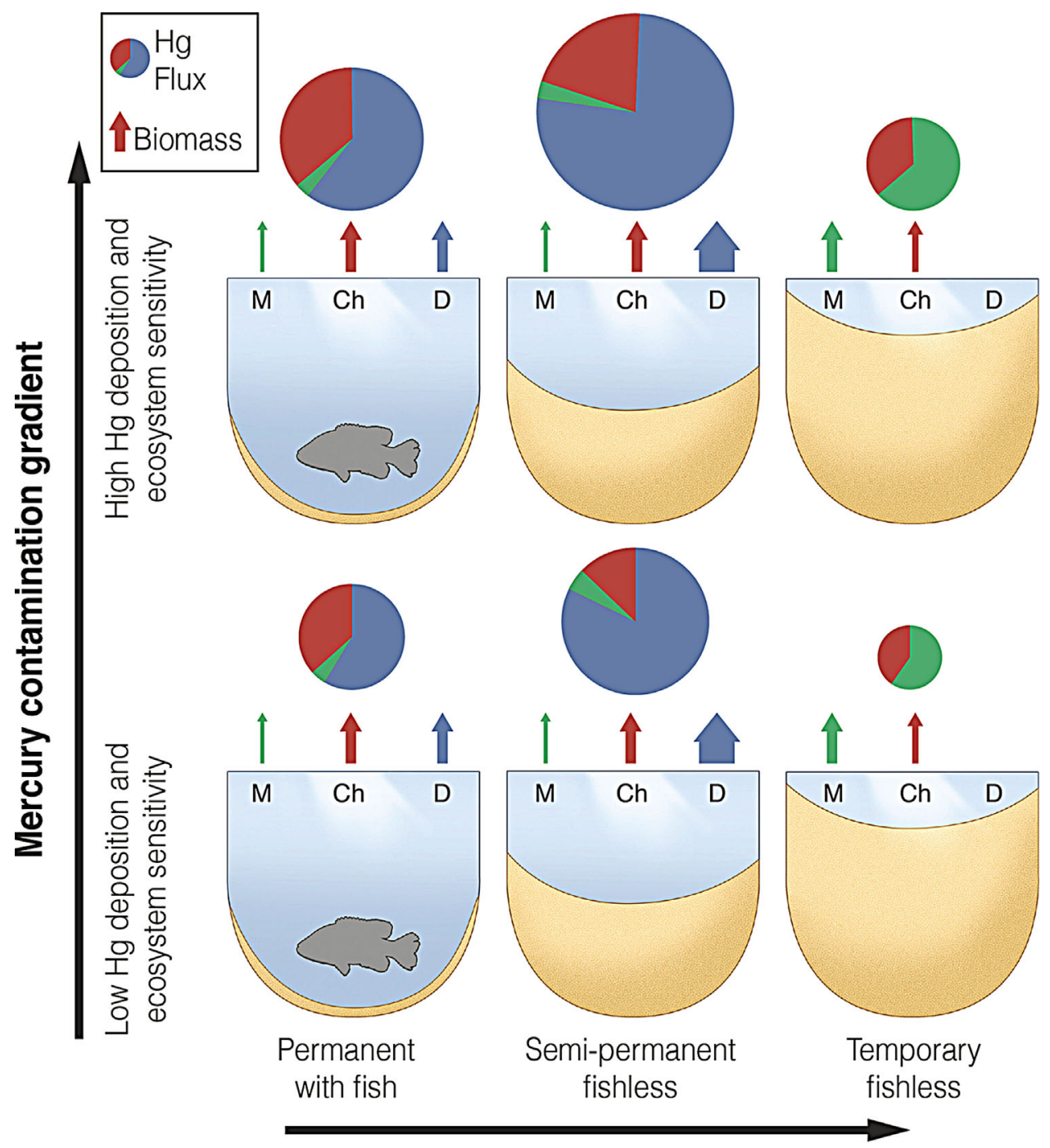

\section{Permanence gradient resulting from sediment infilling}

FIGURE 3: Methylmercury (MeHg) flux in emergent insects is controlled by the interaction of 2 major factors: pond permanence and the level of $\mathrm{Hg}$ contamination of the food web. In general, Hg contamination of the food web is controlled by atmospheric Hg deposition and ecosystem sensitivity to $\mathrm{Hg}$. The thickness of the arrows above the ponds indicates the relative biomass of emerging insects. The pie diagrams indicate relative $\mathrm{MeHg}$ flux. Mosquitoes (M) and chironomids (Ch) are presented as examples of small taxa, and dragonflies (D) are presented as an example of a large taxon. This figure presents a "snapshot" of relative MeHg flux during a period when all 3 pond types contain water. This illustration does not take into account dry periods (when there would be no emergence) and therefore does not reflect annualized MeHg flux for the 3 pond types.

$\mathrm{MeHg}$ flux [9,10]. In permanent ponds with fish, the biomass of small taxa (e.g., chironomids and mosquitoes) and large taxa (e.g., dragonflies) that emerge may be relatively similar [9]. However, large taxa would contribute more to the flux because their $\mathrm{MeHg}$ concentrations are higher [9]. In semipermanent fishless ponds, dragonfly biomass may be considerably larger than chironomid and mosquito biomass in the absence of fish. Dragonflies would account for a large percentage of the total MeHg flux in a semipermanent fishless pond because of their high biomass coupled with a high $\mathrm{MeHg}$ concentration. The elevated biomass of highly $\mathrm{MeHg}$ contaminated dragonflies would also result in a higher $\mathrm{MeHg}$ flux from semipermanent ponds compared with permanent ponds with fish. In temporary fishless ponds, only insects with very short life cycles such as chironomids and mosquitoes could become adults and emerge. The $\mathrm{MeHg}$ flux from temporary fishless ponds would be less than the flux from permanent or semipermanent ponds because of the absence of predatory insects.

We hypothesize that the amount of $\mathrm{MeHg}$ flux for any class of pond is also determined by the degree of $\mathrm{Hg}$ contamination of the food web [9] (Figure 3). In the Great Plains, the primary source of $\mathrm{Hg}$ to ponds is atmospheric deposition. There is a longitudinal gradient in wet $\mathrm{Hg}$ deposition across the Great Plains, with $\mathrm{Hg}$ deposition in the east being up to 7 times greater than $\mathrm{Hg}$ deposition in the west in some years [43]. Although atmospheric deposition is the primary source of $\mathrm{Hg}$ to most aquatic systems [3,4] and $\mathrm{Hg}$ deposition is correlated with $\mathrm{Hg}$ contamination of the food chain [44-46], 


\section{Water-Level Fluctuations and Hg Contamination of Small Human-Made Ponds: An Example of a Factor Associated With Ecosystem Sensitivity to Atmospheric Hg Deposition}

Permanent, semipermanent, and temporary ponds in the southern Great Plains experience extreme annual water-level fluctuations, resulting in most of the pond bottom being exposed during dry periods beginning in the late summer and then rewetting as a result of spring rainfall. Because the basins of human-made ponds are shallow, even a permanent pond that maintains enough water to allow fish to survive during dry periods may have the majority of its sediment exposed during parts of the year. Two small human-made ponds in north Texas are shown to illustrate the extreme water-level fluctuations in permanent (A) and semipermanent (B) ponds during a dry winter (A1, B1) and a wet spring (A2, B2). Because the pictures of the permanent pond (A1, A2) were taken from 2 different perspectives, a peninsula in the permanent pond is marked with a white arrow to facilitate comparison. This annual cycle of drying and rewetting would be expected to create anoxic, carbon-rich conditions conducive to Hg-methylating bacteria in all pond types [5,59]. Indeed, several studies have reported a correlation between water-level fluctuation and MeHg concentrations in biota [59-63]. Because large areas of sediment are exposed annually, we hypothesize that all categories of small human-made ponds in the Great Plains would be sensitive to atmospheric Hg deposition; but we would not expect pond types to differ in the level of food web contamination. In support of this hypothesis we found that invertebrate taxa found in both permanent and semipermanent ponds had elevated, but similar Hg concentrations [8].

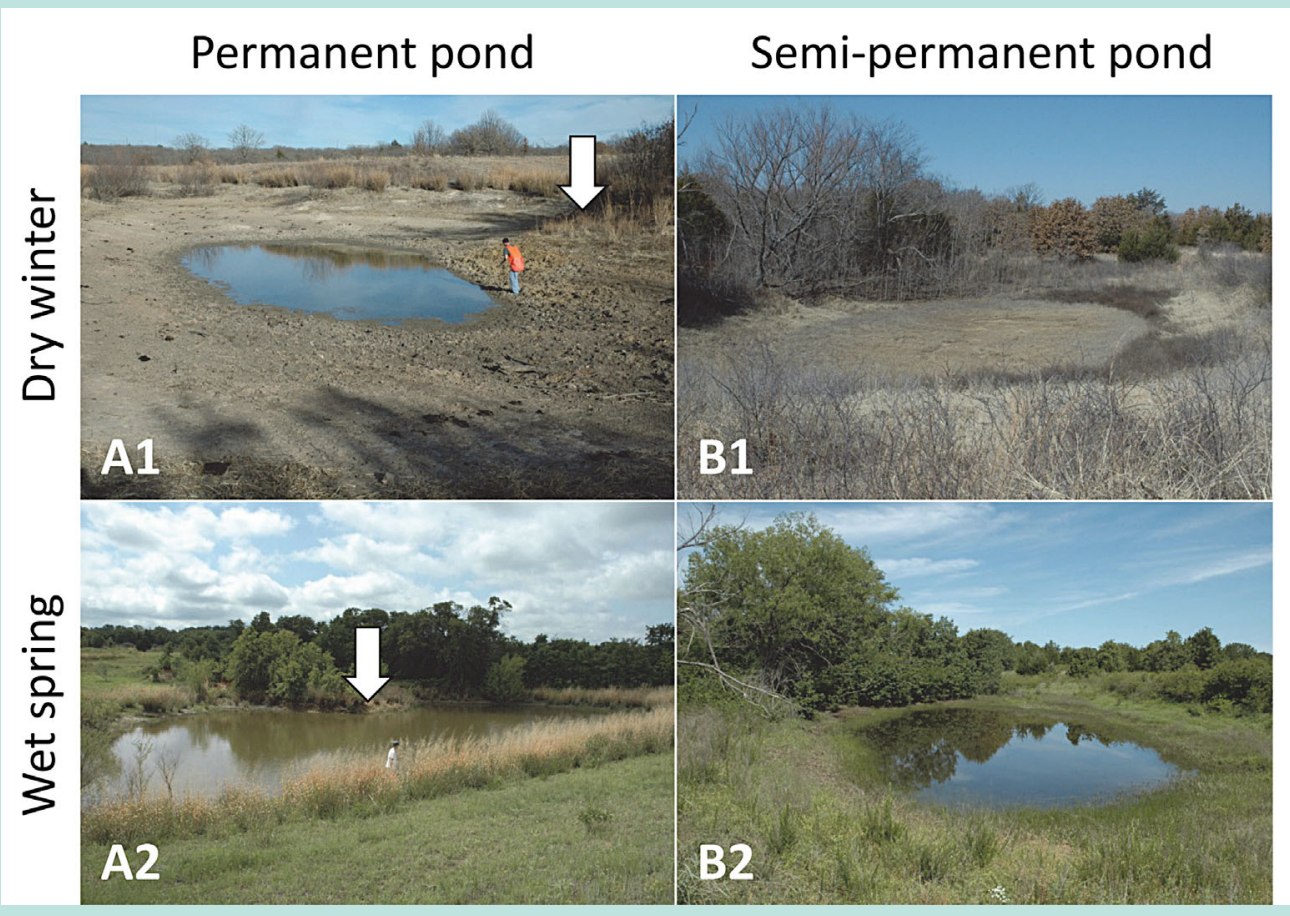

atmospheric deposition of $\mathrm{Hg}$ is not the only determinant of food chain contamination. Some aquatic ecosystems are classified as $\mathrm{Hg}$-sensitive because seemingly small inputs of $\mathrm{Hg}$ from the atmosphere can cause significant $\mathrm{MeHg}$ contamination of fish and wildlife [47]. Factors associated with ecosystem sensitivity to atmospheric $\mathrm{Hg}$ deposition include forests and wetlands within the watershed, shallow water flow paths into the ecosystem, elevated dissolved organic carbon, low productivity, low $\mathrm{pH}$, and water-level fluctuations $[48,49]$. Therefore, ponds receiving elevated $\mathrm{Hg}$ deposition and/or those with characteristics associated with $\mathrm{Hg}$ sensitivity would have more contaminated food webs and would be hypothesized to have elevated $\mathrm{MeHg}$ flux in emergent insects (Figure 3).

\section{Future Research on Emergent Insect-mediated Flux of Mehg From Small Human-made Ponds in a Changing Climate}

\section{Climate change in the Great Plains}

The Great Plains is characterized by strong seasonal climate variations with recurring periods of extended drought (such as the Dust Bowl of the 1930s) alternating with wetter conditions [50]. Significant trends in regional climate are apparent over the last few decades, with increases in average temperatures throughout the Great Plains region [50]. 
A Regional

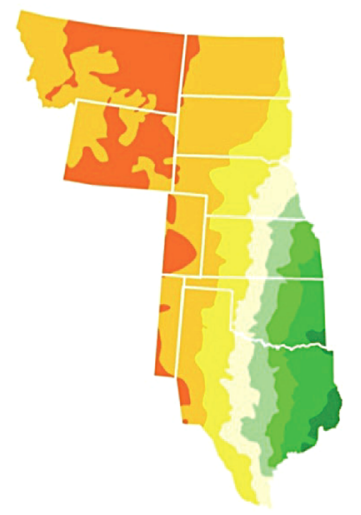

B Watershed

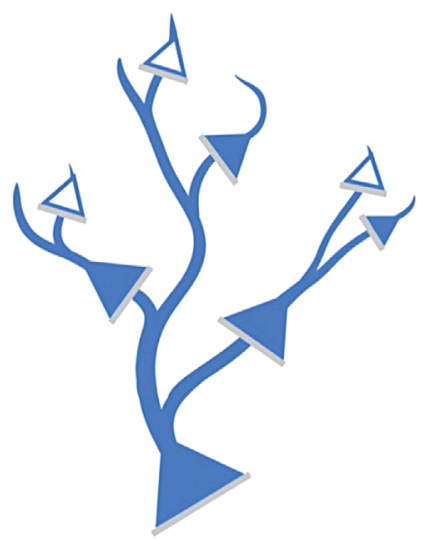

C Pond

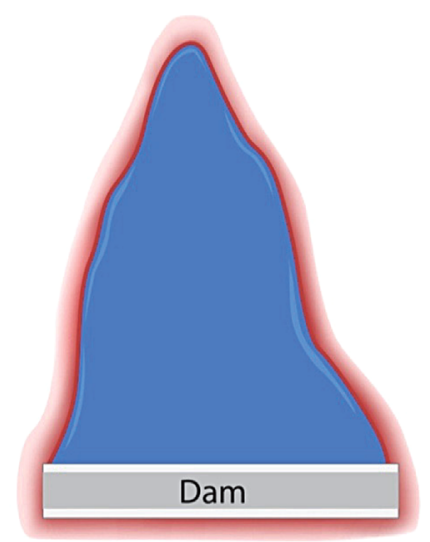

FIGURE 4: Further development and testing of the conceptual model presented will require research at regional, watershed, and pond scales. For example, (A) precipitation patterns vary longitudinally across the Great Plains (figure modified from Bonnin et al. [51]), which may influence patterns of $\mathrm{Hg}$ deposition and pond permanence. (B) The distribution of pond types within a watershed may change as a function of watershed position and may influence patterns of methylmercury $(\mathrm{MeHg})$ flux in a watershed. Open and closed symbols represent temporary or semipermanent and permanent ponds, respectively. (C) Methylmercury originating from emerging insects would be most concentrated near the shoreline and decrease in concentration with distance from the pond, as indicated by the intensity of the red outline.

Temperatures are projected to continue to increase across the Great Plains over this century, and conditions are anticipated to become wetter in the north and drier in the south [50]. Projections of increasing temperatures, faster evaporation rates, more sustained droughts brought on by climate change [50], and human attempts to adapt to the changing climate will likely alter the proportion of permanent, semipermanent, and temporary ponds.

\section{Future research}

Further development and testing of the conceptual model presented in the present column, particularly in the context of a changing climate, will require research at the regional, watershed, and pond scales (Figure 4). Below we present examples of hypotheses that need further investigation to develop models predicting emergent insect-mediated flux of $\mathrm{MeHg}$ from ponds in the Great Plains and how $\mathrm{MeHg}$ flux may be altered by climate change.

\section{Regional scale}

Because rainfall patterns and drought susceptibility vary from west to east across the Great Plains, we hypothesize that there will be longitudinal differences in the proportion of permanent, semipermanent, and temporary ponds. For example, we predict that the greatest abundance of permanent ponds will be in the eastern Great Plains where rainfall is highest [51] (Figure 4A). Factors that may impact insectmediated flux of $\mathrm{MeHg}$ by altering food web contamination of ponds, including wet $\mathrm{Hg}$ deposition [43] and landcover [52], also vary longitudinally across the Great Plains. These factors may interact to produce complex spatial patterns of insectmediated flux of $\mathrm{MeHg}$. An understanding of these spatial patterns will be necessary to predict the effect of climate change on $\mathrm{Hg}$ contamination of the Great Plains.

\section{Watershed scale}

In the Great Plains, we hypothesize that the distribution of pond types within a watershed changes as a function of watershed position and may influence patterns of MeHg flux within a watershed. Smaller temporary and semipermanent ponds may predominate in the upstream portion of watersheds, where low-order streams often have intermittent flow [53] (Figure 4B). The abundance of larger permanent ponds may be greater in downstream portions of watersheds where drainage areas are larger and stream order is higher [54] (Figure 4B). As ponds age, pond permanence may change along the watershed gradient such that the location of temporary and semipermanent ponds may shift to lower positions in the watershed. Reduction of surface runoff predicted by climate change models for the southern Great Plains [50] could further alter the abundance and location of temporary and semipermanent ponds in watersheds.

\section{Pond scale}

We hypothesize that the influence of $\mathrm{MeHg}$ flux on terrestrial food webs varies with distance from the shoreline. We would expect that $\mathrm{MeHg}$ originating from emerging chironomids would be most concentrated near the shoreline and decrease in concentration with distance from the pond (Figure 4C), as has been found for carbon [24,55]. After emergence, dragonflies disperse greater distances than chironomids; and some migratory species may transport $\mathrm{MeHg}$ hundreds of kilometers away from the pond where the $\mathrm{Hg}$ was methylated [56].

\section{Conclusion}

The earth is now in an era of unprecedented global-scale changes caused by human activities [57]. Evidence is 
mounting that environmental stressors, like pollution, climate change, and habitat alteration, exhibit strong interactions with each another as drivers of global-scale changes [58]. Therefore, our understanding of environmental $\mathrm{Hg}$ contamination in the Great Plains and other regions needs to be based on studies of $\mathrm{Hg}$ pollution in the context of climate change and habitat alteration, which includes the construction of small human-made ponds [32].

\section{Acknowledgment}

We thank K. Burgess (onepointline.com) and K. Adams for assistance with figures. The conceptual model discussed in the present column was developed with support from NextEra Energy Resources, Texas Christian University Research and Creative Activities Fund Grants, and a Texas Christian University Invests in Scholarship Grant.

\section{Data Availability}

Data from the present column are available on request from M. Chumchal (m.m.chumchal@tcu.edu).

\section{REFERENCES}

[1] Renwick WH, Sleezer RO, Buddemeier RW, Smith SV. 2006. Small artificial ponds in the United States: Impacts on sedimentation and carbon budget. Proceedings, Eighth Federal Interagency Sedimentation Conference, Reno, NV, USA, April 2-6, pp 738-744.

[2] National Atmospheric Deposition Program/Mercury Deposition Network. 2012. Total Mercury Wet Deposition. University of Illinois, UrbanaChampaign, Illinois, USA. [cited 2014 December 16]. Available from: http:// nadp.sws.uiuc.edu/maplib/pdf/mdn/hg_dep_2012.pdf

[3] Driscoll CT, Mason RP, Chan HM, Jacob DJ, Pirrone N. 2013. Mercury as a global pollutant: Sources, pathways, and effects. Environ Sci Technol 47:4967-4983.

[4] Selin NE. 2009. Global biogeochemical cycling of mercury: A review. Annu Rev of Environment and Resources 34:43-63.

[5] Benoit J, Gilmour C, Heyes A, Mason R, Miller C. 2003. Geochemical and biological controls over methylmercury production and degradation in aquatic ecosystems. ACS Symp Ser 835:262-297.

[6] Speir SL, Chumchal MM, Drenner RW, Cocke WG, Lewis ME, Whitt HJ. 2014. Methyl mercury and stable isotopes of nitrogen reveal that a terrestrial spider has a diet of emergent aquatic insects. Environ Toxicol Chem 33:2506-2509.

[7] Blackwell BD, Drenner RW. 2009. Mercury contamination of macroinvertebrates in fishless grassland ponds. Southwest Nat 54:468-474.

[8] Henderson BL, Chumchal MM, Drenner RW, Deng Y, Diaz P, Nowlin WH. 2012. Effects of fish on mercury contamination of macroinvertebrate communities of grassland ponds. Environ Toxicol Chem 31:870-876.

[9] Tweedy BN, Drenner RW, Chumchal MM, Kennedy JH. 2013. Effects of fish on emergent insect-mediated flux of methyl mercury across a gradient of contamination. Environ Sci Technol 47:1614-1619.

[10] Jones TA, Chumchal MM, Drenner RW, Timmins GN, Nowlin WH. 2013. Bottom-up nutrient and top-down fish impacts on insect-mediated mercury flux from aquatic ecosystems. Environ Toxicol Chem 32:612-618.

[11] Downing JA. 2010. Emerging global role of small lakes and ponds: Little things mean a lot. Limnetica 29:9-23.

[12] Wilbur HM. 1980. Complex life cycles. Annu Rev Ecol Syst 11:67-93.

[13] Swingle HS. 1970. History of warmwater pond culture in the United States. In Benson NG, ed, A Century of Fisheries in North America. American Fisheries Society, Washington, DC, pp 95-105.

[14] Dendy JS. 1963. Farm ponds. In Frey DG, ed, Limnology in North America. University of Wisconsin Press, Madison, WI, USA, pp 595-620.

[15] Ellis EC, Ramankutty N. 2008. Putting people in the map: Anthropogenic biomes of the world. Frontiers in Ecology and the Environment 6:439447.

[16] Downing JA, Prairie YT, Cole JJ, Duarte CM, Tranvik LJ, Striegl RG, McDowell WH, Kortelainen P, Caraco NF, Melack JM, Middelburg JJ. 2006. The global abundance and size distribution of lakes, ponds, and impoundments. Limnol Oceanogr 51:2388-2397.
[17] Smith SV, Renwick WH, Bartley JD, Buddemeier RW. 2002. Distribution and significance of small, artificial water bodies across the United States landscape. Sci Total Environ 299:21-36.

[18] Renwick WH, Smith SV, Bartley JD, Buddemeier RW. 2005. The role of impoundments in the sediment budget of the conterminous United States. Geomorphology 71:99-111.

[19] Batzer DP, Wissinger SA. 1996. Ecology of insect communities in nontidal wetlands. Annu Rev Entomol 41:75-100.

[20] Wellborn GA, Skelly DK, Werner EE. 1996. Mechanisms creating community structure across a freshwater habitat gradient. Annu Rev Ecol Syst 27:337-363.

[21] Williams DD. 1996. Environmental constraints in temporary fresh waters and their consequences for the insect fauna. J North Am Benthol Soc 15: 634-650.

[22] Schneider DW, Frost TM. 1996. Habitat duration and community structure in temporary ponds. J North Am Benthol Soc 15:64-86.

[23] Knight T, McCoy M, Chase J, McCoy K, Holt R. 2005. Trophic cascades across ecosystems. Nature 437:880-883.

[24] Gratton C, Donaldson J, Vander Zanden MJ. 2008. Ecosystem linkages between lakes and the surrounding terrestrial landscape in northeast Iceland. Ecosystems 11:764-774.

[25] Epanchin PN, Knapp RA, Lawler SP. 2010. Nonnative trout impact an alpine-nesting bird by altering aquatic-insect subsidies. Ecology 91: 2406-2415.

[26] Werner EE, Hall DJ. 1976. Niche shifts in sunfishes-Experimental evidence and significance. Science 191:404-406.

[27] Chase JM, Knight TM. 2003. Drought-induced mosquito outbreaks in wetlands. Ecol Lett 6:1017-1024.

[28] Wiener JG. 2013. Mercury exposed: Advances in environmental analysis and ecotoxicology of a highly toxic metal. Environ Toxicol Chem 32:2175-2178.

[29] Scheuhammer AM, Meyer MW, Sandheinrich MB, Murray MW. 2007. Effects of environmental methylmercury on the health of wild birds, mammals, and fish. Ambio 36:12-18.

[30] Cristol DA, Brasso RL, Condon AM, Fovargue RE, Friedman SL, Hallinger KK, Monroe AP, White AE. 2008. The movement of aquatic mercury through terrestrial food webs. Science 320:335-335.

[31] Varian-Ramos C, Swaddle JP, Cristol DA. 2014. Mercury reduces avian reproductive success and imposes selection: An experimental study with adult- or lifetime-exposure in zebra finch. PLOS ONE 9:e95674.

[32] Krabbenhoft DP, Sunderland EM. 2013. Global change and mercury. Science 341:1457-1458.

[33] Miles CJ, Moye HA, Phlips EJ, Sargent B. 2001. Partitioning of monomethylmercury between freshwater algae and water. Environ Sci Technol 35:4277-4282.

[34] Pickhardt PC, Fisher NS. 2007. Accumulation of inorganic and methylmercury by freshwater phytoplankton in two contrasting water bodies. Environ Sci Technol 41:125-131.

[35] Hall BD, Bodaly RA, Fudge RJP, Rudd JWM, Rosenberg DM. 1997. Food as the dominant pathway of methylmercury uptake by fish. Water Air Soil Pollut 100:13-24.

[36] Tsui MTK, Wang WX. 2004. Uptake and elimination routes of inorganic mercury and methylmercury in Daphnia magna. Environ Sci Technol 38:808-816.

[37] Pickhardt PC, Stepanova M, Fisher NS. 2006. Contrasting uptake routes and tissue distributions of inorganic and methylmercury in mosquitofish (Gambusia affinis) and redear sunfish (Lepomis microlophus). Environ Toxicol Chem 25:2132-2142.

[38] Menzie C. 1980. Potential significance of insects in the removal of contaminants from aquatic systems. Water Air Soil Pollut 13:473-479.

[39] Gerrard PM, St Louis VL. 2001. The effects of experimental reservoir creation on the bioaccumulation of methylmercury and reproductive success of tree swallows (Tachycineta bicolor). Environ Sci Technol 35:1329-1338.

[40] Walters DM, Fritz KM, Otter RR. 2008. The dark side of subsidies: Adult stream insects export organic contaminants to riparian predators. Ecol Appl 18:1835-1841.

[41] Walters DM, Mills MA, Fritz KM, Raikow DF. 2010. Spider-mediated flux of PCBs from contaminated sediments to terrestrial ecosystems and potential risks to arachnivorous birds. Environ Sci Technol 44:2849-2856.

[42] Raikow DF, Walters DM, Fritz KM, Mills MA. 2011. The distance that contaminated aquatic subsidies extend into lake riparian zones. Ecol Appl 21:983-990.

[43] National Atmospheric Deposition Program/Mercury Deposition Network 2011. Total Mercury Wet Deposition. University of Illinois, Urbana- 
Champaign, Illinois, USA. [cited 2014 December 16]. Available from: nadp. sws.uiuc.edu/maplib/pdf/mdn/hg_dep_2011.pdf

[44] Drenner RW, Chumchal MM, Jones CM, Lehmann CM, Gay DA, Donato DI. 2013. Effects of mercury deposition and coniferous forests on the mercury contamination of fish in the south central United States. Environ Sci Technol 47:1274-1279.

[45] Hammerschmidt C, Fitzgerald W. 2005. Methylmercury in mosquitoes related to atmospheric mercury deposition and contamination. Environ Sci Technol 39:3034-3039.

[46] Hammerschmidt CR, Fitzgerald WF. 2006. Methylmercury in freshwater fish linked to atmospheric mercury deposition. Environ Sci Technol 40: 7764-7770.

[47] Wiener JG, Krabbenhoft DP, Heinz GH, Scheuhammer AM. 2003. Ecotoxicology of mercury. In Hoffman DJ, Rattner BA, Burton GA Jr, Cairns J Jr, eds, Handbook of Ecotoxicology, 2nd ed. Lewis, Boca Raton, FL, USA, pp 409-464.

[48] Driscoll CT, Han Y, Chen CY, Evers DC, Lambert KF, Holsen TM, Kamman NC, Munson RK. 2007. Mercury contamination in forest and freshwater ecosystems in the northeastern United States. Bioscience 57:17-28.

[49] Evers DC, Han Y, Driscoll CT, Kamman NC, Goodale MW, Lambert KF, Holsen TM, Chen CY, Clair TA, Butler T. 2007. Biological mercury hotspots in the northeastern United States and southeastern Canada. Bioscience 57:29-43.

[50] Karl TR, Melillo JM, Peterson TC. 2009. Global Climate Change Impacts in the United States. Cambridge University Press, New York, NY, USA.

[51] Bonnin GM, Martin D, Lin B, Parzybok T, Yekta M, Riley D. 2006. Precipitation-Frequency Atlas of the United States. National Weather Service, Silver Spring, MD, USA.

[52] Drummond MA, Auch R. 2014. Land-cover change in the United States Great Plains. US Geological Survey, Denver, CO. [cited 2014 December 16]. Available from: http://landcovertrends.usgs.gov/gp/regionalSummary.html

[53] Dodds WK, Gido K, Whiles MR, Fritz KM, Matthews WJ. 2004. Life on the edge: The ecology of Great Plains prairie streams. Bioscience 54:205-216.
[54] Leopold LB, Wolman MG, Miller JP. 1964. Fluvial Processes in Geomorphology. W.H. Freeman and Company, San Francisco, CA, USA.

[55] Gratton C, Vander Zanden MJ. 2009. Flux of aquatic insect productivity to land: Comparison of lentic and lotic ecosystems. Ecology 90:2689-2699.

[56] Wikelski M, Moskowitz D, Adelman JS, Cochran J, Wilcove DS, May ML. 2006. Simple rules guide dragonfly migration. Biol Lett 2:325-329.

[57] Vitousek PM. 1994. Beyond global warming-Ecology and global change. Ecology 75:1861-1876.

[58] Mantyka-Pringle CS, Martin TG, Rhodes JR, 2012. Interactions between climate and habitat loss effects on biodiversity: A systematic review and meta-analysis. Global Change Biology 18:1239-1252.

[59] Larson JH, Maki RP, Knights BC, Gray BR. 2014. Can mercury in fish be reduced by water level management? Evaluating the effects of water level fluctuation on mercury accumulation in yellow perch (Perca flavescens) Ecotoxicology 23:1555-1563.

[60] Brooks RT, Eggert SL, Nislow KH, Kolka RK, Chen CY, Ward DM. 2012 Preliminary assessment of mercury accumulation in Massachusetts and Minnesota seasonal forest pools. Wetlands 32:653-663.

[61] Selch T, Hoagstrom C, Weimer E, Duehr J, Chipps S. 2007. Influence of fluctuating water levels on mercury concentrations in adult walleye. Bull Environ Contam Toxicol 79:36-40.

[62] Sorensen JA, Kallemeyn LW, Sydor M. 2005. Relationship between mercury accumulation in young-of-the-year yellow perch and water-level fluctuations. Environ Sci Technol 39:9237-9243.

[63] Snodgrass JW, Jagoe CH, Bryan J, Lawrence A, Brant HA, Burger J. 2000. Effects of trophic status and wetland morphology, hydroperiod, and water chemistry on mercury concentrations in fish. Can J Fish Aquat Sci 57 $171-180$.

[64] Simley JD, Carswell WJ Jr. 2009. The national map-Hydrography. US Geological Survey Fact Sheet 3054. US Geological Survey, Washington DC.

[65] US Environmental Protection Agency . 2013. Ecoregions of North America USEPA, Washington, D.C. [2014 December 16]. Available from: http:// www.epa.gov/wed/pages/ecoregions/na_eco.htm 